learning to read comprise only part of the complex of factors which constitute general intelligence, and he quotes results of experimental tests showing that the age at which children begin to read is influenced by the teacher and classroom atmosphere as well as by their parents. To him, reading is a 'decoding' operation which is simpler in a language like Finnish, in which there is a consistent relation between the code and its phonemes, than in English with its multitude of ambiguities and complexities. In some other languages, orthographies present a different set of problems.

To meet difficulties of this kind, a new code called the Initial Teaching Medium has been devised, which is based on an alphabet and spelling simpler than the medium in which most beginners' books are printed. Its advantages are that it contains fewer ambiguities, it is less complex, in reading it the eyes move continuously from left to right, never having to reverse, and there are fewer items to be learned for phonemes and whole words. Working with the Initial Tesching Medium, children can begin to read earlier; in other words, reading readiness is related to the complexity of the reading code.

Learning to write is an 'encoding' process distinct from learning to read. Not only does it depend on the coordination of a different set of muscles for working with pencils or crayons, but it involves the mastery of an orthography distinet from that which is used in print. Downing refers with favour to developments in the Responsive Environments Laboratory of Yale University, where O. K. Moore is attempting to by-pass some of these difficulties by encouraging children to use ordinary electric typewriters as well as a computer-controlled 'talking' typewriter which can 'talk back' to the child. It has been found that children between $2 \frac{1}{2}$ and 6 years of age can use the ordinary keyboard, and that they enjoy the experience. Moore emphasizes that as children learn to type they ought to master the elements of punctuation, which are also part of the encoding system; and Downing suggests that a simple design of typing machine, capable of reproducing 43 letters of the augmented alphabet used in the Initial Teaching Medium, could be mass-produced cheaply, and that under school conditions machines of this kind could be made available for use along with paper, penoils, crayons and ink. Then they might help to bring a child's reading and writing into line with his listening, speaking and thinking.

Taking the three papers together, one is impressed by the importance and diversity of the issues on which they touch, yet at the same time by the slight amount of attention which is being directed to them in the British Commonwealth, or indeed, apart from the United States, in any part of the world. In our present-day civilization, communication holds a central place. Immense advances have been made in the development of new media, like the telephone, cinema, radio and television, but so far, little has been done to bring the older, traditional forms. including the structure of language, the alphabet, spelling, the shape of letters, and along with them, reading and writing, and even speaking, up to date. These are points of cardinal importance in relation to what is destined to become the premier language in the world. Then, of course, there is the question what people read after they have become literate; but that problem brings up other considerations.
R. Weatherall

\title{
THE NETHERLANDS REACTOR CENTRE
}

$\mathrm{T}$ WO illustrated brochures in English have recently been issued by the Netherlands Reactor Centre (Reactor Centrum Nederland). The first* gives a general survey of the reactors $H F R$ (high-flux reactor), $L F R$ (lowflux reactor) and $K R I T O$ (critical experiment reactor) at the research establishment at Petten and of the research carried out by the various departments, and the second $\dagger$ is a summary of the activities of the Centre during the period January 1, 1962-June 30, 1963, together with financial details for 1962 .

The Reactor Centrum Nederland, a foundation set up on July 6, 1955, consists of a Board of Governors of forty members and a Board of eleven members, representing the Netherlands Government, the electricity producers, a number of Dutch industries, and the Foundation for Fundamental Research on Matter, which is the body mainly supporting nuclear research in the Dutch univer. sities and colleges. The chairman of both Boards is Dr. E. L. Kramer.

The reactor $H F R$ became critical for the first time during November 1961, but the reactor tank was found to have defective welds and a now tank was installed during February 1962. The power was then gradually increased to the $20 \mathrm{MW}$ for which the installation was designed. In November 1962 the reactor was transferred to Euratom to become the principal installation of the new Euratom research centre adjoining the site of the Reactor Centrum Nederland at Petten. The agreement between the Netherlands Government and the Euratom Commission stipulates that for the first four years at least the HFR will be operated for Euratom by the Reactor Centrum Nederland and that the Dutch irradiation programme will have priority so far as this reactor is concerned.

* The Research of Reactor Centrum Nederland, General Survey of Activities, 1963. Pp. 35. Issued by External Relations, RCN (August 1963).

t Reactor Centrum Nederland. Summary of Activities, January 1962 July 1963. Pp. 16. (The Hague: Reactor Centrum Nederland, 1963.)
The Enrico Fermi Building for Experimental Reactor Physics has been completed and houses the $10-\mathrm{kW}$ 'Argonaut' type reactor $L F R$ and, in the closed concrete hall which forms part of the north wing of the building, the reactor KRITO, which became critical on March 28, 1963. KRITO is a zero-energy reactor, designed by the Reactor Centrum Nederland and built entirely by Dutch firms, and is an important part of the NERO reactor dovelopment programme carried out in association with Euratom. The programme comprises experiments for the development of a 61-MW (thermal) pressurized water reactor suitable for ship propulsion. The Reactor Centrum Nederland has collaborated with a German indus. trial combination interested in the design of an advanced pressurized water reactor for the German experimental nuclear vessel and has taken part in the Netherlands working group studying a 52,000-ton tanker equipped with a pressurized water reactor. This investigation was one of three-the others in Scandinavia and France-for the European Nuclear Energy Agency of the Organization for Economic Co-operation and Development.

The Evaluation and Design Department of the Reactor Centrum Nederland has been concerned with three research reactor projects. The first was BARN (Biological Agricultural Reactor Netherlands), a $100-\mathrm{kW}$ swimming-pool reactor, built at the Institute for the Application of Atomic Energy to Agriculture, near Wageningen. The fissile material is $3,400 \mathrm{~g} 90$ per cent enriched uranium. Water is both moderator and coolant, and the reactor, which became critical on April 9, 1963, has two irradiation channels and a thermal column. The second project was that of $E C O$, a critical experiment to be installed at the Euratom establishment at Ispra, and the third, a small research reactor of the 'Argonaut' type designed for the Technological University at Eindhoven. 
Both brochures mention work carried out jointly with the Norwegian Institutt for Atomenergi at Kjeller, near Oslo. About twenty Dutch technicians are working at Kjeller on six different projects, and six Norwegians are assisting with five other joint projects at Petten. At the KEMA laboratories in Arnhem, work on the development of a homogeneous reactor is continuing in collaboration with Euratom. The nuclear fuel for this reactor is to be a suspension of $\mathrm{ThO}_{2}-\mathrm{UO}_{2}$ particles in water, and the aim is to develop a reactor in which an equal amount of fissile material is produced as that consumed. Methods have been developed for the production of suitable par- ticles-smooth, densely sintered spheres of $2-3 \mu$ diameter and a 250-kW suspension test reactor KSTR (KEMA Suspension Test Reactor) is being designed. Tests have been made of the damage caused by irradiation of the suspension particles and it has been shown that the degree of damage is strongly dependent on the acidity of the colloid suspension. For these tests new measuring techniques had to be developed, for the investigation consists of colloid chemistry at temperatures above $100^{\circ} \mathrm{C}$ and represents an entirely new field in the science of chemistry.

\title{
FLUORIDE METABOLISM IN PLANTS
}

\author{
By SIR RUDOLPH PETERS, F.R.S., and M. SHORTHOUSE \\ Department of Biochemistry, University of Cambridge
}

$\mathrm{T}$ HE fact that some plants (Chailletaciae) in Africa, especially Dichapetalum cymosum (gifblaar) and other species, synthesize fluoroacetate $\left(\mathrm{F} . \mathrm{CH}_{2} \cdot \mathrm{COOH}\right)$ raises the general question whether the synthesis of the $\mathrm{FC}$ bond is a general property of plants. More recently another plant has been added to the list; the Acacia georginae from Central Australia makes fluoroacetate ${ }^{1,2}$. Against the idea that such a synthesis is a general property of plants, there are several known facts.

Among several veterinary investigations, one may quote the recent one made by Shupe et al..$^{3}$ on cows; the effects of fluoride ingestion lod to fluorosis, to change in the bones and teeth. Even so, it took about 4 years for these to develop on diets containing 45 p.p.m., and 2 years on 95 p.p.m. Shupe et al. observed no alterations in the soft tissues and no effect on the calves. Such experiments do much to eliminate any latent fear that dosing with small amounts of fluoride may give rise to fluoroacetate. It seemed, however, that there was need for an investigation of the fluoride metabolism of grass, to make sure that it did not synthesize the CF bond. Some preliminary experiments in this direction were made by one of us with $\mathrm{Mr}$. R. J. Hall at Babraham, Cambridge, in which a plot of grass was watered. This was kindly put at our disposal by the director, Dr. I. de Burgh Daly. These did not give decisive results. It was thought that a more direct test on seedlings exposed to varying concentration of fluoride would give more information. These experiments form the basis of this article.

The method published by R. J. Hall ${ }^{4}$ was used. In this the diffusion method of Singer and Armstrong ${ }^{5}$, somewhat modified, is followed by a modified colorimetric estimation, depending on the formation of an alizarin complexan (Belcher et $a l .{ }^{6}$ ). Diffusion is carried out at $60^{\circ} \mathrm{C}$ from strong perchloric acid. With this method one can detect with reasonable accuracy amounts of fluoride from $0.2 \mu \mathrm{g}$ to $1 \cdot 0 \mu \mathrm{g}$. $0 \cdot 1 \mu \mathrm{g}$ can be detected with errors up to 11 per cent. As devised, the method makes possible the investigation of fluoride metabolism in small samplings of grass seedlings.

Grass seedlings 14-16 days old from Carter's Mixed Seed Invicta with rye grass in lots of $1.0 \mathrm{~g}$ (about 20 seedlings) were exposed in beakers for varying periods of time and concentration of fluoride. The 29 experiments done included grass grown on vermiculite, and muslin and 'Terylene' on water. Analyses were made of inorganic fluoride, fluoride acid labile on diffusion, total fluoride by combustion at $600^{\circ} \mathrm{C}$, and alkali labile fluoride.

Exps. $a$ and $b$ in Table 1 show that grass takes up Ffrom fluoride solutions. $1 a$, one out of 4 experiments, indicates that this increases from 1 to $4 \mathrm{~h}$ exposure at $1.05 \mathrm{mM} ; 1 b$, that increase of fluoride concentration up to $21.0 \mathrm{mM}$ much increases the uptake. In our early experi- ments we found 'extra' fluoride by combustion, here ealled total fluorido, that is, the total $\mathrm{F}^{-}$was greater than inorganic $\mathrm{F}^{-}$. We experienced some difficulty in accounting for this, but we now consider that fluoride is also present in the insoluble residue and that differences found between total and inorganic $\mathrm{F}$ were due to failure to remove com. pletely the last traces of 'solids' from the supernatants.

\begin{tabular}{|c|c|c|c|c|c|c|c|}
\hline Exp. & $\begin{array}{l}\text { Seedlings } \\
\text { grown for: }\end{array}$ & Conc. & at $1.0 \mathrm{~h}$ & $\begin{array}{l}\text { Content } \\
2 \cdot 0 \mathrm{~h}\end{array}$ & $\begin{array}{c}\text { f inorgan } \\
3.0 \mathrm{~h}\end{array}$ & $\begin{array}{l}F(\mu \mathrm{g} / \mathrm{g} \\
4.0 \mathrm{~h}\end{array}$ & $16 \cdot$ \\
\hline (a) & $\begin{array}{l}19 \text { days } \\
14 \text { days }\end{array}$ & $\begin{array}{r}1.05 \mathrm{mM} \\
5.25 \mathrm{mM} \\
10.50 \mathrm{mM} \\
15.75 \mathrm{mM} \\
21.00 \mathrm{mM}\end{array}$ & $\begin{array}{l}28^{1 \cdot 5} \\
34 \\
40 \\
51\end{array}$ & $\begin{array}{l}1 \cdot 5 \\
39 \\
45 \\
80 \\
94\end{array}$ & $\begin{array}{l}1 \cdot 7 \\
= \\
=\end{array}$ & $\begin{array}{l}3 \cdot 4 \\
30 \cdot 0 \\
31 \\
55 \\
62\end{array}$ & $\begin{array}{r}\overline{58} \\
68 \\
161 \\
282\end{array}$ \\
\hline
\end{tabular}

$1.0 \mathrm{mM}=19$ p.p.m.

1.0-g samples (about 20 whole seedlings) were exposed in diffused light to NaF- in water. After the time stated, the seedlings were thoroughly washed were then weighed and ground in cooled mortar with 1 per cent perchloric acid $(2.0 \mathrm{ml}$.). After centrifuging, the solid was washed three times and supernatants and residue anslysed separately.

In support of this, Table 2 gives details of two recent experiments. It shows clearly that when all precautions are taken, even with high concentrations of fluoride representing 300 and 200 p.p.m., no organic fluoride is formed. This view was confirmed by experiments made in the course of the work, where we have not been able to find any extra $\mathbf{F}$ - liberated in this way by alkaline hydrolysis, a characteristic of fluoroacetate. Further, an extract of grass seedlings exposed to fluoride had no fluoroacetate effect on guinea pig kidney homogenate, that is, no extra accumulation of citrate by our usual tests?

Table 2. ANalysis of INORganic and TOTal FluORIDE TAKEN UP BY 2. ANALYSIS OF INORGANIC AND TOTAL FLUORIDE TAK

\begin{tabular}{|c|c|c|c|c|c|}
\hline \multirow{2}{*}{$\begin{array}{l}\text { Seedlings } \\
\text { grown for: }\end{array}$} & \multirow{2}{*}{$\underset{(m M)}{\text { Conc. F- }}$} & \multirow{2}{*}{$\begin{array}{l}\text { Time of } \\
\text { exposure }\end{array}$} & \multicolumn{2}{|c|}{$\begin{array}{l}\text { Fluoride }(\mu \mathrm{g} / \mathrm{g}) \\
\text { supernatant }\end{array}$} & \multirow{2}{*}{$\begin{array}{c}\text { Residue } \\
\text { total }\end{array}$} \\
\hline & & & Inorg & Total & \\
\hline $\begin{array}{l}11 \text { days } \\
17 \text { days }\end{array}$ & $\begin{array}{l}15 \cdot 75 \\
10 \cdot 50\end{array}$ & $\begin{array}{l}56 \mathrm{~h} \\
4 \text { days }\end{array}$ & $\begin{array}{r}1,500 \\
448\end{array}$ & $\begin{array}{c}1,515 \\
461\end{array}$ & $\begin{array}{l}>200 \\
>40\end{array}$ \\
\hline
\end{tabular}

Details of the experiments were as in Table 1.

In a search through the literature we have only found one instance in which the actual uptake of fluoride has been estimated. Applogate, Adams and Carriker ${ }^{8}$ using seedlings of Phaseolus vulgaris (minus cotyledons) have determined fluorido taken up at 3 stages of growth in different strengths of fluoride. There was not much difference in uptake between the light and dark. When exposed to $1.0 \mathrm{mM} \mathrm{F}$ - the uptake of inorganic $\mathrm{F}$ was 22 $\mu \mathrm{g} / \mathrm{g}$. An increase to $10.0 \mathrm{mM}$ gave an increase of ten times, and with $100 \mathrm{mM}$ the uptake was $2,846 \mu \mathrm{g} / \mathrm{g}$. In our case a rather steep rise for a long exposure took place between 10.5 and $15.75 \mathrm{mM}$.

Concentrations of total fluorine may reach $10.0 \mathrm{mM}$ in the soil, but of this only a small amount is present in a 